\title{
Dualidades e tensões no Fausto de Goethe. Um ensaio
}

\author{
Dualities and Tensions in \\ Goethe's Faust. An Essay
}

\author{
Pedro Fernandes Galé \\ Universidade Federal de São Carlos (UFSCar)
}

\section{RESUMO}

Esse ensaio busca apresentar as dualidades presentes nos primeiros movimentos da ediçáo de Fausto como elementos constituintes da formação do todo da obra. É a própria caracterização dual que garante à obra o estatuto de tragédia. Buscando estabelecer relações com as polaridades abordadas por Goethe, essa leitura dual se faz de acordo com alguns postulados teóricos do próprio autor e é uma ferramenta que auxilia a compreensão dessa obra.

\section{PALAVRAS-CHAVE}

Goethe; Tragédia; Fausto; Polaridade.

\begin{abstract}
This essay aims to present the dualities found in the first movements of Faust's finished edition as constituent elements of the formation of the whole of the work. It is the dual characterization itself that guarantees the work the status of a tragedy. Seeking to establish relations with the polarities addressed by Goethe, this dual reading is done according to some theoretical postulates of the author himself and is a tool that helps the understanding of this lifetime work.
\end{abstract}

\section{KEY WORDS}

Goethe; Tragedy; Faust; Polarity. 


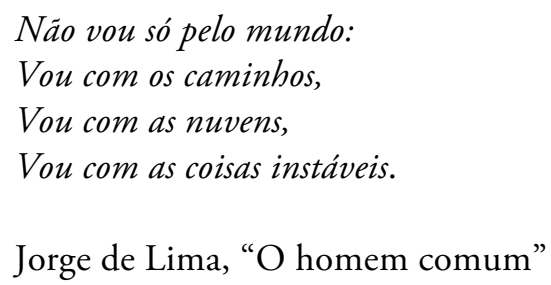

Pensar as dualidades, ou ainda, as polaridades, como elementos constituintes do Fausto de Goethe não é reduzir uma obra de caráter literário a qualquer sorte de sistema, ou ainda, de sistema filosófico. A intenção desse ensaio é a de mostrar que o elemento dual que se apresenta já nos movimentos de abertura da tragédia atua como algo que gera a tensão que propulsionará a obra como um todo. Embora o autor confesse não possuir órgão para a filosofia, não se pode negar que questóes de cunho filosófico tenham sido ocupação frequente do poeta. Em se tratando de uma obra que fora definida como Summa Summarum de sua vida, questóes desta sorte, bem como muitos traços de seu modo de pensar, se encontram embrenhadas nos seus mais de doze mil versos. Sem esquecermos o gênero ao qual Goethe buscava atender, tentaremos mostrar que é nas tensôes geradas por polaridades que o todo da obra parece ganhar formas das mais diversas. As dualidades aqui, em similaridade ao que aconteceria em suas obras acerca da natureza, atuam enquanto forças rítmicas que, como nos aponta Maria Filomena Molder, inscrevem-se "numa metodologia estritamente descritiva, procurando fazer sobressair as energias estruturantes, as formas e os ritmos, que dão origem a configuraçóes concretas, as mantêm e transformam." (Molder, 1995, p. 210). Não se trataria de entender a infinitude que consiste o Fausto, mas em detectar essas forças no caráter rítmico dessa obra.

Ao publicar em I808 a parte primeira de seu Fausto, Goethe deu-lhe o subtítulo de "Primeira parte da tragédia". O leitor que acompanha os passos dados pela personagem central até o fim da obra se coloca uma série de questôes, a mais evidente delas é acerca de seu gênero. Seria a obra, nessa sua primeira versão mais, digamos, completa uma tragédia pela apresentaçáo terrível do destino de Margarida? Em sendo assim, por que Fausto, ainda em sua edição final, já com as duas partes, póstuma, deve ser lido como uma tragédia? Diversas respostas podem ser pensadas diante dessa questão, tentaremos aqui apresentar, ainda que em forma de ensaio, uma busca pela forma estruturante do Fausto para que possamos entender o que seria o seu elemento trágico. Um dos caminhos mais evidentes para tal resposta é recuar milênios e observar a definição dada por Platáo, no célebre Livro X de sua República, da poesia mimética, ou seja, da tragédia: "A poesia mimética, dizíamos 
nós, imita homens entregues a açóes forçadas ou voluntárias, e que, em consequência de as terem praticado, pensam ser felizes ou infelizes, afligindo-se ou regozijando-se em todas essas circunstâncias." (Platão, 200I, p. 466 - 603 c)

A relação entre a tragédia e a ação, posta de modo muito claro por Aristóteles, "é, pois, a tragédia a imitação de uma ação de caráter elevado, completa e de certa extensão" (I986, p. IIo), seria para Goethe central em sua peça trágica. A questão se torna mais complexa se pensarmos naquilo em que se pautaram os que pensaram a tragédia, ou seja, a continuação desta definição clássica aristotélica, no que diz respeito ao que a tragédia é capaz de despertar: "em linguagem ornamentada e com as várias espécies de ornamentos distribuídas pelas diversas partes [do drama], [imitação que se efetua] não por narrativa, mas mediante atores, e que, suscitando o terror e a piedade, tem por efeito a purificação dessas emoçôes" (Ibid.).

Seria uma resposta fácil e tranquila dizer que é a partir da definição platônica que se deu a inclinação trágica da obra de Goethe. Mas não seria efetiva a reflexão que daí se poderia extrair. A estrutura do Fausto, em seu todo, extrapola todas as unidades clássicas da tragédia, a de ação, de tempo e de lugar, ainda assim, o poeta a apresenta sob a nomenclatura de Tragödie. Lembrando de seu pendor à antiguidade clássica, isso deve ser entendido como uma possuindo alguma afinidade com a passagem acima mencionada. Em seu "Comentário à poética de Aristóteles" ele parece dar um caminho para que compreendamos esse aspecto: "Como poderia Aristóteles, enquanto fala da construção da obra trágica em sua maneira de pensar dirigida aos objetos, pensar no efeito, ainda mais no efeito distante que uma tragédia talvez viesse a ter sobre o espectador? De maneira alguma!" (Goethe, 2000, p. I8).

Goethe parece já ter pensado nesse aspecto ao compor sua peça trágica. Há elementos que nos permitem dizer que há uma coerência entre a obra que o poeta elaborou desde a juventude e seu ensaio sobre Aristóteles que ganhou luz nos anos 20 do século XIX. Esse modo de entender a tragédia, exposto por sua maneira de entender as passagens do filósofo de Estagira, apresenta clara oposição àquilo que o jovem Schiller escrevera em seu ensaio "Sobre a arte trágica":

Para a natureza, o deleite pode ser apenas um fim mediato; para a arte, ele é o mais alto. Faz parte, portanto, primordialmente do fim dessa última náo negligenciar o alto deleite que está contido na comoção triste. Mas a arte que póe particularmente como seu fim o deleite da compaixão se chama, no entendimento universal, [arte trágica] [...] A arte trágica imitará, assim, a natureza das açóes capazes de despertar primordialmente o afeto compassivo. (Schiller, 20I8, p. 46-47) 
Esse aspecto do pensamento artístico já havia sido combatido por Goethe em outras ocasióes, mas é na sua obra Viagem à Itália que esse embate com o que podemos chamar de estética do efeito aparece de modo mais claro. Tudo ocorre diante de uma paisagem da antiguidade, os promontórios e a costa da Sicília, onde ele compara os antigos e os modernos:

Permita-me exprimir meu pensamento de maneira concisa: eles apresentam a existência, nós geralmente o efeito; eles descrevem o terrível, nós descrevemos terrivelmente; eles retratam o agradável, nós de maneira agradável, e assim por diante. É daí que advém todo exagero, o maneirismo, toda graça falsa, todo empolamento. $E$ isso porque, quando se trabalha o efeito e visando ao efeito, acredita-se não ser possível torná-lo palpável o bastante. (Goethe, I999, p. 379)

Trabalhar o efeito seria para ele uma das grandes deficiências de uma arte da modernidade. Sua preocupação está na linha de um modo de se alcançar o elemento trágico. Há algo que seria uma retomada de Aristóteles, que ele intentou colocar diante do homem moderno, de modo tensionado: "a tragédia não é imitação de homens, mas de ação e de vida, de felicidade [e infelicidade; mas felicidade] ou infelicidade reside na ação, e a própria finalidade da vida é uma ação, não uma qualidade." (Aristóteles, 1986, p. III). Esse clamor trágico para a ação, presente desde a descrição de Platáo no modo de se pensar a poesia trágica tem de se chocar com o mundo moderno, com o seu sujeito e com sua ciência. A tragédia de Fausto é a tragédia da ação assimilada à descrição moderna do trágico sublime, que ganha nas linhas das Cartas sobre o dogmatismo e o criticismo, de Schelling uma descrição muito precisa: "Certamente essa luta contra o imensurável não é somente o mais sublime que o homem pode pensar; é, no meu entender, o próprio princípio de sublimidade." (Schelling, 1978, p. 179).

É nas ações de um homem, cujo ímpeto moderno diante do imensurável se coloca de modo trágico e aniquilador, que a tragédia ganhará seu tom. É na tensão entre esse homem moderno, voltado ao interior, e a ação, que se projeta ao exterior, ao mundo, que uma dessas polaridades já se nos apresenta. A própria escolha por intitular a obra como Fausto: uma tragédia, já indica o modo de operar de toda a obra. Pois segundo a sua interpretação da Poética, catarse se ligaria à reconciliação das paixóes, em um círculo reconciliatório "que é procurado, na verdade, em todo drama, ou até mesmo em todas as obras poéticas" (Goethe, 2000, p. I8). Essa reconciliação, ainda segundo o poeta, acontece na tragédia

por meio de um sacrifício humano, que pode realmente ser levado a cabo, ou solucionado por uma compensação, sob a influência de uma divindade favorável, como é o caso de Abraão e de Agamenón: onde uma conciliação ou 
solução são indispensáveis, no fim, se a tragédia for uma obra poética perfeita. (Ibid., p. I8-I9)

O que a tragédia parece buscar como um todo é a exibição da própria necessidade de um fator de conciliação. Tomemos as linhas que encerram a dedicatória, para que de alguma forma encontremos esse tom na obra:

Apossa-se de mim uma olvidada [falta] / Desse reino calmo e grave / Dos espíritos e a minha ciciada / Canção, eólia harpa, é voo de ave; / Estremeço ao pranto a lágrima ajuntada / O peito austero torna leve e suave: / O que possuo dilui-se na distância, / E o que [desaparecera torna-se para mim realidade]. (Fausto, versos 25-32 $2^{1}$ )

Aqui é a persona do poeta que se apresenta como que diante de um móbile trágico, é nessa chave de apresentar o que é fugidio porém de algum modo passível de uma efetivação que devemos entender os móbiles que levam à ação trágica já desde seus primeiros momentos. É na direção de um reino de uma moderna espiritualidade que a intenção de se compor uma tragédia, gênero antigo por excelência, se coloca diante do mundo que se fazia alterar desde o racionalismo clássico de Descartes. A obra tende a ampliar, de modo discursivo, aquilo que, em última análise, não é passível de figuração.

É necessário, diante da maior das exigências da tragédia, ou seja, imitar uma ação, colocar como atuantes uma série de aspectos que coloquem a operar as mais afiadas faculdades humanas, como nos indica o cômico no célebre prólogo no teatro: "Coragem, pois, mostrai vossa maestria: / Razão, Entendimento, sentimento, paixão / Deixai soar os coros da fantasia, / E que loucura não falte, atenção!” (Versos, 8587). O âmbito da tragédia é descrito, e com ele o de toda a poesia, como o daquilo que o homem traz em si, potências humanas devem apresentar-se de modo a estarem afinadas ao coro da fantasia, da loucura à razão devemos buscar algo que traga à baila uma ordenação de algum tipo. É ao poeta que coube primeiro essa conciliação entre as coisas do mundo e as potências humanas. A harmonia ganharia uma pretensa objetividade pela ordenação, ainda que fantasiosa (e pensemos a fantasia como potência positiva e propositiva), do poeta. É ao poeta que clama o cômico. É do caráter de toda a poesia, segundo Goethe, buscar o "círculo conciliatório", é à própria poesia que devemos a operação de fazer o que não aparece tornar-se presente e que o presente se perca na distância.

É a poesia que traz a conciliação do homem com aquilo que se afasta da experiência comum. O que é posto a atuar é uma espécie de instinto do homem, algo que

1 Utilizarei sempre, aqui, da tradução de João Barrento, com alteraçōes de minha lavra inseridas entre chaves. 
tinha em Winckelmann, um dos pais do Classicismo de Goethe, uma proposta interpretativa que é, ainda que em parte, retomada pelo poeta que ganha voz no prelúdio aos Monumenti antici Inediti spiegate ed ilustrati, a saber, a de que

Tudo na natureza, embora em sua formação tenda ao perfeito, é impedido de ser perfeito pela matéria e de diversos acidentes a que ela e a humanidade estáo sujeitas. Ora, a essa imperfeiçáo se tentou suprir com um instinto do homem, que quer se alçar para além de sua sorte, corrigindo o que na natureza é deixado imperfeito, e, por outro lado contribuiu a imaginaçáo dos gentios na direção de sua religião, cujos primeiros instrutores foram os poetas. [...] Para idearem simulacros dos mais dignos da divindade e mais propensos à ligaçáo com a fantasia dos homens, exprimiram a permanência dos deuses em sua eterna juventude e primavera da vida, alusivas à condiçáo do Ser supremo e capaz de induzir a alma humana num doce delírio do amor em que consiste a alegria que buscam os mortais em todas as religiōes. (Winckelmann, 20II, p. 66-67)

Leitor de Winckelmann, e mais do que isso organizador do volume Winckelmann e seu século, em I805, Goethe parece remontar essa visão nesse prólogo que coloca em debate as figuras do cômico, do diretor e do poeta. É o poeta que chama para si essa figuração, essa apresentação do natural e do divino:

Enquanto a natureza fia o fio / No seu fuso infinito, indiferente, / E um sem número de seres em desvario / se faz ouvir, dissonante e demente - / Quem anima e divide a sempre igual / Sequência e a dá ritmicamente? / Quem sagra a parte no rito universal, / $\mathrm{E}$ a faz vibrar em acordes imponentes? / quem desenfreia a fúria das paixôes? Quem póe o fogo nas almas o poente? / Quem esparge na primavera os botôes / De belas flores nas veredas dos amantes? / Quem faz de folhas sem significado / coroas de glória, para o valor distinguir? / Quem garante o Olimpo para os deuses Unir? / A potência humana, no poeta revelado. (Versos I44-I57)

Ao que o cômico responde: "Usai essa bela força/ e conduzi os negócios da poesia!” (Versos I58-I59). É a essa menção dos negócios da poesia que se opóe, de certa forma, a poesia como um todo; o que a poesia busca é a reconciliação do homem com o mundo. O poeta busca apresentar a natureza, bem como o essencial da divindade, buscando sanar o seu aspecto mais central: o fato do divino ser remoto e abstrato, assim como a natureza, que em seu caráter é insondável e superior às potências humanas que de algum modo se veem presas às coisas sensíveis e nelas encerra o seu registro. Isso obriga que o poeta, munido de fantasia, busque, ainda que por meio de alegorias e outros recursos poéticos, os movimentos e açóes que revestem a Existência incriada e a natureza. A missão máxima da poesia é a da reconcili- 
ação. Por meio do engenho coordenado que faz presente o que é ausente, apresentando o que nem mesmo é apresentável, ela traria para diante dos homens o aspecto insondável que deve se transferir para a realidade mais usual. É diante dessa mediação, o ofício próprio do poeta, que o prólogo se encerra de modo quase que irônico diante da grandeza da empresa, o diretor ao final desse movimento declara: "Vamos abrir-vos neste humilde barracão / Todo o círculo da criação / Seguindo em ritmo certo, o ciclo eterno, / Do céu para a terra e desta para o inferno." (Versos 239-243)

Essa tensão, a partir dos polos aqui expostos como a realidade ordinária, colocada por uma instalação módica e o todo da criação afirma a tensão diante da possibilidade da apresentação do que é do âmbito do divino e natural em sua possibilidade de efetivação artística. A tensão entre o humilde barracão, ou melhor, uma casa de madeira (Breterhauss, lembrando que Bretter é também palco) e o insondável se apresenta como metáfora material da sempre insuficiente relação entre palavras e coisas. Isso se agrava, é claro quando é no estatuto do divino que se move o poeta; retomando os dizeres de Mefistófeles acerca do doutor Fausto, "Não é terreno o pasto desse insensato!" (verso 300²).

Esse movimento em direção ao supralunar, trazido à baila "por um recurso cênico reminiscente do "teatro dentro do teatro", que segundo Haroldo de Campos faria parte de "um manifesto estético virtual, no qual um diretor, um poeta e um bufẫo mediador discutem sobre o drama alemão" (Campos, I98I, p. II2), mas mais do que isso podemos dizer que nesse prólogo há algo de modelar em relação ao que transcorrerá no todo dessa tragédia. Segundo o mesmo Haroldo de Campos, podemos notar, em certa medida, que há "Algo de Deus-Padre no diretor, algo de Mefistófeles no bufão e algo de Fausto na altanaria atribulada do velho poeta" (Ibid., p. II3). Vemos aqui a própria dimensão trágica como possibilidade de conciliação, é no poeta que se conciliam os ímpetos do Diretor e do Cômico, é ele que traz à cena a açáo que todos desejam ver.

A própria e irreconciliável apresentação do mundo, e mais precisamente o divino, enquanto cena e teatro, aparece como que de modo operacional como ordena o diretor: "Por isso não poupemos nesta peça / Nem máquinas, nem truques, nem cenários. / Usemos as duas luminárias / Em estrelas sejamos generosos, / Não falte água, fogo, montes rochosos, / Nem tampouco aves e animálias." (Versos 233-238). A carpintaria cênica que se coloca como que a indicação do teatro do mundo se vê como simulacro da máquina do mundo que, dada sua dimensão extensiva, permite

2 Aqui na tradução de Agostinho D’Ornellas, por ser, nessa passagem, mais bela. 
que adentremos a abóbada celeste, dentre as falanges dos anjos, na presença de Mefistófeles e do próprio Deus.

O prólogo no céu, como nos indica Ferdinand Weinhandl (Metphysik Goethes, p. 370) só se torna compreensível se o entendermos simbolicamente. Já em suas primeiras linhas se colocam diante do leitor os três arcanjos. Para além da já conhecida apresentação de um modelo Ptolomaico do mundo por Rafael e da visão copernicana colocada por Gabriel, há um movimento dual de esferas e o sublunar que, nas palavras do primeiro, se apresenta a partir da canção das esferas celestes (Versos 243-245) até o "sonoro trovão" e no segundo das revoluçôes da terra (Versos 25I-253) e "Em largas vagas espuma o mar, / Descendo ao fundo dos penhascos, / E rocha e mar vai arrastar / O ciclo célere dos astros.” (Versos 255-258). É na figura do Arcanjo Miguel, o anjo da força, que o mundo sublunar se mostra em todo o seu vigor: "Furacóes rugem à porfia, / Do mar à terra, da terra ao mar; / Irados, formam a cadeia / De ecos profundos em redor. / Chameja o raio arrasador / No trilho antes do trovão. / Teus mensageiros, porém Senhor, / Veneram-te na paz da Criação.” (Versos 259-266). O Cantar dos anjos traz a imagem de uma cosmologia que é fundada num movimento puro e que se apresenta como dualidades que se sucedem, da música perfeita das esferas ao trovão a rugir, do movimento celeste da terra à paisagem sublime nela contida, assim como da força do mundo sublunar à veneraçáo calma da divindade (e aqui o movimento é ascendente) o que se coloca é a relação com a obra do Senhor, como cantam os três em coro: "Ver-Te dá aos anjos vigor, / Insondável é Teu mistério, / E o esplendor da Obra em redor / É como o do primeiro dia." (Versos 267-270). O que os anjos parecem apresentar é um movimento que Luiz Roberto Monzani tão bem descreveu:

Concepção geocêntrica universo esférico, que supunha uma divisão entre o mundo sublunar e o supra lunar, ambos submetidos a ordens diferentes, onde a noção de "lugar natural" ocupa um posto central e, em consequência disso, a noção de movimento retilíneo sempre aponta para uma "desordem cósmica", uma "ruptura de equilíbrio" e deve sempre ser passageira. Cosmos ordenado, fechado, hierarquizado, onde cada objeto tem seu lugar determinado. (Monzani, 1995, p. 65)

Esse movimento que sai do modelo ordenado da harmonia das esferas e se desloca para a natureza terrível descrita por Miguel se apresenta como que em retilíneo deslocamento na direção de um universo "onde o cosmos desmembra-se de um lado, e de outro unifica-se, porque não há um acima e um abaixo, regulado por normas diferentes"; nesse caminho, aponta Monzani, "o universo homogeneiza-se" (1995, p. 66). Essa instabilidade dada pela presença de um movimento retilíneo se faz apresentar-se de modo quase hiperbólico, pois, ainda que as razôes de veneração 
ao Senhor sejam tocadas pelos três momentos desse deslocamento, o movimento se faz descender ainda um passo mais em relação ao cosmos organizado. $\mathrm{O}$ cosmos, homogêneo ou fechado e hierarquizado, parece, em seu célere movimento para baixo, deixar espaço para a figura que, no seu caráter de negação, reforça a própria celeridade dos modelos, entra em cena Mefistófeles.

Nesse deslocamento "do céu para a terra" há um efeito quase que colateral, em sua célere imersão, não poderia deixar de contemplar o elemento maligno da negação. $\mathrm{O}$ abandono do universo antigo, ordenado e operando diante de uma hierarquia, parece trazer à socapa o abandono da "hierarquia objetiva dos valores, que culmina na noção de 'summum bonum'" (Ibid.), faz com que a ideia de que o bem seja "uma estrutura objetiva que está incrustada na realidade" (Ibid.) dê lugar a uma mobilidade dos valores que permite que, num movimento oposto, o de ascendência do mal, do mundano, se coloque diante da canção dos anjos. O que ganha a cena é uma cena dialógica entre as maiores forças rítmicas do universo, "o sagrado, o conflito escatológico do Bem e do Mal, se recompóe pela medida do homem" (Campos, I985, p. 8I). Da canção das esferas à figura do velho doutor Fausto, o que se vê é o movimento que se configura a partir do zênite da criação, de um cosmos ordenado, segue até a inconstância da alma humana. É a própria figura do elemento maligno que introduz, como um fulgor retilíneo diante das esferas e mundos, a questão do homem: "De sóis e mundos nada sei nem direi / Que os homens se atormentam disso sei." (Versos 278-279)

É o homem, diante do cosmos, que atrai a sanha do elemento maléfico e parece fazer um contraponto, uma oposição, à perfeição e à sublimidade terrível da própria criação. O elemento mais novo e móvel na criação parece ganhar luz diante da dinâmica da cosmologia, móvel, é verdade, apresentada pelos anjos: "O pequeno deus do mundo não mudou / desde o primeiro dia, mui singular ficou.” (Versos 28I-282) é esse o elemento que o espírito que nega traz para o âmbito das ordens celestes. Retomando a passagem de Leibniz, em sua Teodiceia, como nos indica o comentário de Albert Schöne, para a edição da obra da Deutsche Klassiker Verlag, (v. 2, p. 169), o que Mefisto parece trazer é que "O homem, então, é como um pequeno deus no seu próprio mundo, ou microcosmo, que ele governa a seu modo" (Leibniz, 20I7, p. 238). Mais do que um coincidir poético em relação a Leibniz, mais do que trazer ao corpo de sua tragédia uma indicação do autor da Monadologia, Goethe parece querer que busquemos a passagem que aqui reproduzimos. E é claro que ela se vê desarticulada e adornada pelo linguajar irônico de Mefistófeles. Pois é nessa passagem do item 147 da segunda parte da Teodiceia que o filósofo fala da aparente desordem daquilo que diz respeito ao homem (Ibid.), essa aparente desordem parece advir do fato de "Deus lhe presenteia com uma imagem da divindade quando lhe 
oferece inteligência” (Ibid.). E é assim que que Deus parece se ocultar do jogo posto que Ele "não entra aí [no microcosmo] senão de maneira oculta, pois fornece ser, força, vida, razão sem se fazer ver" (Ibid.).

Ao falar do homem, o espírito de negação parece se ressentir do fato de que Deus "o abandona aos seus sentidos" e por isso "O homem sente-se mal à medida que erra; mas Deus, com maravilhosa arte, transforma todos os defeitos desse pequeno mundo no maior ornamento de seu grande mundo." (Ibid., p. 239). Cravar, de fato, que é a partir de tais passagens que Goethe escreve seria um passo que não podemos dar, mas as coincidências são, no mínimo, convincentes. Na figura de um pequeno deus, o homem se coloca diante da criação, das altas esferas, como o elemento que lançado nesse mundo de devir, parece ter problemas exatamente pelo fato de que "Deus lhe presenteia com uma imagem da divindade quando lhe oferece a inteligência" e é por isso que encontramos "uma razão particular da desordem aparente no que se refere ao homem” (Ibid., p. 238). Nas palavras de Mefistófeles o homem "Viveria melhor, se não fosse enganado / Pelo Lampejo de Luz com que lhe haveis dotado; / Razão lhe chama, e serve afinal / Para ser mais bicho que qualquer animal." (Versos 283-286)

O elemento de negação parece querer demonstrar o problema do lugar do homem em uma teodiceia dessa sorte: se a entrada do divino, que permanece oculto aos homens, é pela via do ser, da força, da vida e da razão, é por esse último regalo que os homens se tornam mais que brutos, brutais, animalizados, assemelhando-se diz ele a cigarras, que "[Sempre voam e voando saltam / e novamente na grama entoam a mesma canção] / Se ao menos ficasse no prado / Mas quer meter o nariz em todo lado!" (Versos 289-292). A razão, que seria o princípio da ação nos homens, enquanto centelha da divindade, transforma o homem naquele para quem não há lixo em que o nariz não meta, a canção, porém, permanece a mesma. A imagem da divindade o faz alçar-se para além de si mesmo. Munido desse presente, o homem, que em salto voa, mas à relva volta, sempre pode entoar a canção terrena, sempre em muito distante daquela que nas palavras de Rafael "Seguindo o antigo ritmo, o Sol / com as esferas canta uma canção" (Versos 243-245). Essa canção terrena não parece bastar a esse "pequeno deus" em aparente desordem.

Não haveria escalada possível para a condição humana. $\mathrm{O}$ que a personagem diabólica parece indicar é o caráter cindido do homem, que quer participar da unidade das ordens mais elevadas. Isso se coloca de modo em que a própria linguagem, que "na sua negatividade, póe tudo à bulha, dessacraliza tudo, crenças e convicçóes. O alto e o baixo nele coexistem, aproximados em convívio derrisório; a tirada filosófica e o termo chulo podem alternar-se, o divino e o misterioso se humanizam" (Campos, 1985, p. 79). O que ocorre é que, cerceado diante da possibilidade de 
divinização do humano, o que o elemento de negação traz à tona é a possibilidade de humanizar o que é divino, o recurso primevo dos poetas. É assim que o Ente Supremo se apresenta e, diante do espírito que sempre nega, sua entrada se faz de modo a não conter uma afirmação sequer. É com uma sequência de três perguntas que Ele ganha voz: "Só tem notícias dessas para dar? / Vens até mim apenas para se queixar? / [Não há nada na terra que seja para ti certo?]" (Versos 293-295) Ao que o espírito de negação responde, como haveria de ocorrer, com uma negação "Senhor Não!" (Nein Herr!) (Verso 296).

Diante do elemento ligado ao não ser e a efetividade circular do maior âmbito do ser, ou seja, o próprio Deus, vemos externada a maior das polaridades, a maior "daquelas oposiçôes cuja pertença recíproca não pode ser erradicada" (Molder, 20I7, p. 4I). Nesse diálogo entre as trevas e a luz, Goethe parece mais uma vez dar "a ver que essas oposições engendravam auto-expressividades diferenciadas - engendramento a que ele chamou de intensificação." (Ibid.). A expressão mais clara desse engendramento é a própria condição humana diante de um mundo onde "Está tudo em tal estado / Que metem dó os homens nesse vale de misérias / Já nem apraz a mim aos pobres fazer pilhérias." (Versos 293-295). Nesse caminho de formaçôes e de positivação onde é na intensificação das oposiçôes que algo toma forma, em analogia às forças de expansão e contração que "permitem o desenvolvimento da planta, isto é a metamorfose da folha desde os cotilédones até ao fruto" (Molder, 20I7, p. 4I), a figura de Fausto surge pela primeira vez. O diálogo, sai do âmbito generalizante e ganha corpo ao redor de uma existência singular. Aquilo que se referia a toda humanidade, à condição humana, se vê efetivado na figura do doutor; as forças opostas, bem e mal, luz e trevas, dão existência e individuação àquilo que era geral:

Cada existente é um analogon de todo o existente. Daí que nos pareça a existência simultaneamente unida e separada. Se seguimos em demasia a analogia, tudo se torna idêntico; se a evitamos tudo se diversifica indefinidamente. Em ambos os casos, a contemplaçáo fica estagnada: no primeiro como sobrevivente, no segundo como morta. (Goethe, 1997, p. 126)

As generalidades se colocam agora diante de um existente, numa analogia moderada. É dual também esse procedimento poético e de todo conhecer. É nessa chave que devemos entender a entrada da personagem central da tragédia. Mais uma vez, o supremo Ser faz uma questão: "[Fausto, conheces?], ao que o interlocutor, o espírito que nega responde também com uma questão "O doutor?" Ao que o Senhor responde com Sua primeira e enfática afirmação: “Meu [servo]!” (Versos 298-299). Diante desse analogon da condição humana mais uma vez Mefistófeles reafirma o 
seu espírito de negação: "[Maneira singular tem de servir-Te] / Não é terreno pasto desse insensato ${ }^{3}$ / Fervilha nele a febre da distância, / Vive meio consciente da loucura; / Pede as mais belas estrelas sua ânsia, / Do mundo os maiores prazeres procura, / E nem o que à mão tem, nem a distância / Satisfazem essa alma insegura." (Versos 300-307)

Esse é Fausto, aquele que, de um lado quer alçar-se para além do humano e ao mesmo tempo quer, nas palavras de Mefistófeles, se refestelar nos prazeres mundanos. Ele, em analogia à persona do autor, também se vê num mundo dual, onde, como já vimos, vê diluir-se na distância o que possui e o que não lhe pertence ganha efetividade. Esse dualismo, sem qualquer sorte de conciliação, ao ver do elemento diabólico, se apresenta aqui como uma polaridade que parece paralisada entre dois impulsos que se anulam, o pequeno deus se quer alçado às esferas elevadas e ao mesmo tempo quer penetrar nos veios da vida mais mundana. $\mathrm{O}$ embate se dá entre duas naturezas; uma que como nos indica Ernst Österkamp é a afirmação de Deus "na legitimidade e harmonia interna" (20IO, p. 515 ) diante da qual "o entendimento da desproporção entre a sagrada completude da natureza e o desejo de saber do homem" levariam a "uma doença profunda e narcisista" (Ibid., p. 5I4); a outra se relaciona com o elemento maléfico: "onde o diabo está, a natureza não é amada, mas consumida e desgastada” (Ibid., p. 5I8).

Fausto é apresentado por Mefistófeles como possuindo em si os tormentos advindos da reprodução da polaridade que se manifesta nos céus; ele próprio, seria também um analogon do embate sagrado do bem e do mal, transposto à mundanidade da existência humana. Como pequeno deus se vê inserido na dinâmica de um universo, regido por um Senhor justo, nesse mundo, ainda que pequeno, "não existe nada", nos diz Leibniz, "que se oponha à unidade de um princípio universal infinitamente perfeito; ao contrário, elas [as deformidades do pequeno mundo] aumentam a admiração de Sua Sabedoria, que faz com que o mal sirva um bem maior." (20I7, p. 239)

É essa a unidade, cuja dinâmica, Mefisto, faz questão, mais adiante, de se mostrar cônscio, que o elemento de negação vai querer colocar a prova. E o Senhor parece remontar a positividade na atuação humana diante do princípio universal e se coloca de modo a negar a dúvida do próprio demo, com um tratamento em relaçáo ao seu opositor matreiro que náo deixa de surpreender. A irreconciliável polaridade se apresenta aqui na própria forma com que Deus se dirige ao espírito que a tudo, inclusive a Ele, nega:

\footnotetext{
3 Aqui na tradução de D’Ornellas.
} 
"Se é certo que hoje me serve em confusão / Em breve eu o trarei à claridade. / Verdeja a árvore, e sabe o hortelão / Que flor e fruto hão-de vir com a idade." (Versos 308-3II)

Ao que o espírito da negação responde com um desafio:

"Vai uma aposta? Eu Vos digo em verdade, / Que o haveis de perder! Basta eu poder / Conduzi-lo bem à minha vontade." (Versos 312-314)

Os registros do modo de "falar" das duas figuras alegorizam a própria polaridade, a afirmação e a negação, o ser e o não ser, o bem e o mal, se dá de modo a deixar claro a diferença de registros que se apresentará, como mais uma dualidade, no todo da obra, onde baixo e elevado se fazem desenvolver de modo a se assemelhar ao modo pelo qual a natureza opera. Suas forças de expansão e contraçáo, enquanto processos de efetivação, permitem que as etapas da forma vivente ganhassem o mundo.

Em toda essa parcela inicial do Fausto, as tensôes iniciais são como que a mola propulsora que se expande na direçáo dos polos, uma tensão entendida como "o estado de aparente repouso de uma energia totalmente preparada para se manifestar, para se diferenciar, para se polarizar." (Goethe, I997, p. 237). É nessa diferenciação que a obra vai descendendo, em seus primeiros movimentos, a níveis cada vez mais individualizados num processo de polaridade e tensão que se reafirma cada novo movimento do polarizar-se. É nesse sentido que o Deus desse prólogo se transforma em um Deus da ação, que faz uso até mesmo do espírito que nega, para que a ação do homem não esmoreça; as últimas palavras do Senhor são, portanto, quase que a contraçáo dos motivos da obra, de suas polaridades, ao aceitar a aposta, e permitir que Mefistófeles leve o doutor a seu talante:

"Fica à vontade, e vem quando quiseres; / De todos os espíritos que negam, / É o velhaco o que menos me agasta. / A ação do homem depressa se atenua. / Em pouco tempo já quer repouso inteiro. / É bom por isso mandar-lhe um companheiro / que o espicaça, o incita, como o diabo atua." (Versos 336-343)

E depois se dirige aos anjos:

"E vós, veros filhos do divino, / À beleza animada cantai vosso hino! / O que está em devir e eternamente vive / vos prenderá nos doces laços do amor, / E vós fixai a aparência livre / E fugaz em pensamento fundador." (Versos 344- 349)

Em tais passagens, que encerram a voz de Deus, se apresentam algumas hipóteses para que pensemos o aspecto trágico da obra. Esse Deus que impele e clama por ação, ainda que isso lhe custe aproximar dos homens o espírito de negaçáo, parece 
junto com seus verdadeiros filhos, os arcanjos, indicar o modo de proceder da natureza. Nela o fenômeno livre e sua aparência, bem como o pensamento que a fixa, se encontram unidos. Para que isso fique claro retomemos uma passagem dos Escritos Morfológicos de Goethe:

Desde os primeiros elementos físicos e químicos, até os produtos racionais dos homens, todos obedecem a este válido princípio: nós mesmos mudamos assim como o que possui forma. [...] A forma é um mover, um porvir, um passar. Uma teoria da forma é uma teoria da mudança. A teoria da metamorfose é a chave que tudo abre na natureza. (Goethe, 1993b, p. 349)

É nesse registro que as coisas se sucedem do mesmo modo em que as polaridades atuam: "sempre gradualmente atuante, e através da transformação de uma forma na outra". Sob esta chave acompanhamos "uma escala espiritual, [que] se eleva até àquele zênite da natureza que é a reprodução pelos dois sexos”. (Goethe, I993a, p. 35). Nesse processo nos afastamos do mundo das perfeitas esferas e do regular. Como nos aponta Cassirer, em Goethe nunca estamos diante de um mundo geometrizado e estático, do qual seria possível uma imagem fixa, mas de um mundo que se apresenta "em termos absolutamente dinâmicos. Sem renunciar, muito menos, ao constante, não reconhece como mais favorável o constante que aquilo que se manifesta por meio do devir e em relação a este." (Cassirer, I998, p. 173)

$\mathrm{O}$ regular e o irregular no campo da ação possuem um valor análogo. $\mathrm{O}$ devir e o transitório teriam o mesmo valor da forma fixada pelo movimento e açóes das forças da natureza. Nela "as modulaçóes destes ritmos excedem sempre a nossa capacidade discursiva, porque são dotados de capacidade viva de inovar em cada momento da sua manifestação" (Molder, I995, p. 209). É diante dessas polaridades e as subscrevendo que o divino vai se manifestar no Fausto. Atuando como ritmo e polaridade esses são princípios de "formação e especificação, expansão e contração - que regem a harmonia, que ditam o próprio ritmo do mundo", como nos indica Márcio Suzuki (2005, p. 209). São análogos a esses princípios aqueles que se veem atuando no impulso trágico da obra.

Atuando como forças geradoras de uma tensão, essas polaridades, geradoras de outras polaridades, que se fazem apreender no embate entre o céu e o inferno, serão também a presença do divino no próprio protagonista da tragédia. Isso se dará no interior de um sujeito que também se vê condicionado por essas forças que atuam no mundo "a sístole e a diástole do espírito do mundo (Weltgeist), que obviamente não se encontra em parte alguma, mas apenas na conformação geral do todo" (Ibid.), como analogon de todo existente, essas condiçóes formadoras atuam também na personagem que dá nome à tragédia, como o próprio Fausto confessa: "Duas almas 
possuo eu em meu peito / Uma da outra a querer-se separar: / Uma apega-se em paixão rasteira, com todos seus olhos à matéria; / Outra quer erguer-se da poeira / E subir ao reino da sua origem etérea. / Oh, se existem espíritos no ar / Que entre a terra e o céu tem assunto / Que se dignem da nuvem de ouro descer / Para me dar novo alento." (Versos III-I2I). É a partir dessa tensão entre as duas almas que algo vai ter de interceder para que o doutor Fausto se encaminhe para a açáo, pois, segundo Goethe, "A teoria, de um lado, e a experiência/fenômeno, de outro, estão em conflito permanente. Qualquer unificação no âmbito da reflexão é ilusória, só através da ação é que se pode unificar" (Goethe, 1997, p. 233).

Lembremos que é nesse momento que entra em cena, ainda que oculto, Mefistófeles, na imagem de um Poodle negro que se encontrava nas cercanias. Essa polaridade tensa, de almas que se digladiam buscando a separação no espírito insatisfeito que não permite nenhuma sorte de síntese, exige a intromissão daquele que em suas próprias palavras é "Da força uma parcela - /que quer sempre o mal e o bem faz nascer dela" (Versos I36-I37). "Sou o espírito que só sabe negar / E com razáo: tudo o que vês / É digno apenas de morrer outra vez. / Melhor seria, pois, nada nascer. /Assim, tudo que no nosso dizer / É pecado, ruína, em suma, o mal / — esse é o meu elemento original." (Versos I38-I44). É somente "sob a influência de uma divindade favorável" que o sacrifício de Fausto dá lugar a uma série de açóes. A tragédia que primeiramente foi impedida pelo repicar dos sinos da páscoa, ou seja, o seu suicídio (Versos 720-737) dá lugar a essa intromissão.

A natureza vivente e morrente faz o contraponto à negaçáo implícita no elemento maligno que diante do devir e do cambiante busca estagnaçáo. Mais uma vez aquele que tem no mal o intento, só o bem causa. Pois a violência com que Fausto encarou a natureza no episódio do espírito da terra, que o relegou ao plano "do espírito que entendes, / Náo a mim!" (versos 5IO-5II), dá lugar ao amor à natureza. E Deus, agora longe da cena, nela se manifesta; não se trataria de um Deus-natureza que se manifestaria diretamente nas operaçóes do mundo, mas de um Deus que da harmonia celeste passa a atuar no ritmo do mundo, ritmo que a cada movimento de tensáo, polaridade, tensão e, novamente, polaridade e assim ao infinito, se mostra em seu poder efetivador, a própria onipresença divina se apresentaria, entáo, no ritmo das polaridades que, como sístole e diástole, efetivam o mundo do espírito e das formas. Esse Deus seria, em última análise, o princípio mesmo da ação, ele atua na natureza ainda que não se confunda com a sua figuração.

O divino é que garante a ação, que na segunda parte vai se tornar vertiginosa: "O que de mais alto recebemos de Deus e da natureza é a vida, o movimento de rotação em torno de si mesmo, o qual não conhece descanso nem repouso" (Goethe, I997, p. 9I). É diante dessa atuação, que faz uso até mesmo da negação, que a partir 
de seus mais iniciais passos Goethe nos entrega uma tragédia e nos apresenta seus móbiles, pois em concordando com Aristóteles e Platáo acerca da ligação central entre a tragédia e a ação, poderíamos pensar que, nesse ritmo dual que gera a ação, o que se tem aqui é a própria tragédia primordial, pois nela o que se lê, nesse processo rítmico entre polaridades e tensôes, são os próprios móbiles mais recônditos da ação. A ação, que para Aristóteles, juntamente com o mito, seria "a finalidade da tragédia” (Aristóteles, I986, p. III), alça-se para além do seu espectro trágico. A ação se coloca como algo tão central e efetivo que, em sua tradução do gênesis, Fausto, diante da célebre passagem "No princípio era o verbo", declara o verbo como insuficiente ("Tanto não vale o verbo" - Verso I226); depois de passar por traduçôes como "pensamento" (Verso I229) e "Energia" (Verso I233), ele declara convicto: "Vale-me o Espírito, já vejo a solução, / Escrevo confiante: 'Ao princípio era a ação!'” (Versos I236-I237).

\section{Referências bibliográficas}

Aristóteles. (1986). Poética. Tradução de Eudoro de Souza. Lisboa: Imprensa Nacional - Casa da moeda.

Campos, H. (198I). Deus e o diabo no Fausto de Goethe. São Paulo: Perspectiva.

Cassirer, E. (1998). El problema del conocimiento IV. Tradução de Wenceslao Roces. México D. F.: Fondo de cultura económica.

Goethe, J. W. (1993a). A metamorfose das plantas. Tradução de Maria Filomena Molder. Lisboa: Imprensa Nacional — Casa da moeda,.

Goethe, J. W. (200o). Escritos sobre literatura. Tradução Pedro Süssekind. Rio de Janeiro: Editora 7 letras.

Goethe, J. W. (1994). Faust (2 v.) (Albrecht Schöne - Organização e comentários). Sämtliche Werke. Briefe Tagebücher und Gespräche, v. I5. Frankfurt am Main: Deutscher Klassiker Verlag.

Goethe, J. W. (2000). Fausto. Tradução de João Barrento. Lisboa: Relógio d'água. Goethe, J. W. (1996). Fausto. Tradução de Agostinho d'Ornellas. Lisboa: Relógio d'água. Goethe, J. W. (2004). Fausto. Tradução de Jenny Klabin Segall. São Paulo: Editora 34.

Goethe, J. W. (1997). Máximas e reflexôes. Tradução de Afonso Teixeira da Mota. Lisboa: Guimarães Editores.

Goethe, J. W. (1993b). Schriften zur Morphologie. Sämtliche Werke. Briefe Tagebücher und Gespräche, v. 24. Frankfurt am Main: Deutscher Klassiker Verlag.

Goethe, J. W. Viagem à Itália. (1999). Tradução de Sérgio Tellaroli. São Paulo: Cia. Das Letras.

Leibniz. G. W. (20I7). Ensaios de Teodicéia. Tradução de William Piauí e Juliana Cecci. São Paulo: Estação Liberdade. 
Molder, M. F. (2017). Dia alegre, dia pensante, dia fatal. Lisboa: Relógio d'água.

Molder, M. F. (I995). O pensamento morfológico de Goethe. Lisboa: Imprensa Nacional - Casa da moeda.

Monzani, L. R. (1995). Desejo e prazer na idade moderna. Campinas: Ed. Unicamp.

Österkamp. E. (200o). “Amor e violência: a natureza de Fausto”. In: Galle e Mazzari (org.). Fausto e a américa Latina. Sáo Paulo: Humanitas.

Platão. (200I). A República. Aristóteles. Poética. Tradução de Maria Helena da Rocha Pereira. Lisboa: Calouste Gulbenkian.

Schelling, W. F. (1974). Cartas sobre o dogmatismo e o criticismo. Os pensadores, v. XXVI. Tradução de R. R. Torres Filho. Sáo Paulo: Abril Cultural.

Schiller, F. (2018). Objetos Trágicos, objetos estéticos. Tradução de Vladimir Vieira. Belo Horizonte: Autêntica.

Suzuki, M. (2005). "A ciência simbólica do mundo". In: Novaes. A. (org.). Poetas que pensaram o mundo. São Paulo: Cia das Letras.

Winckelmann, J. J. (20II) Monumenti antici Inediti spiegate ed ilustrati. Mainz: Philipp von Zabern Verlag. 